ラマン分光法を用いたアクリル系上塗り材の劣化指標

高谷 哲* 仁科 勇輝 $*$ 羽村 陽平 $* * *$
山田 卓司 $* * * *$ 佃 洋一 $* * * *$ 山本 貴士 ${ }^{*}$ 高橋良和*

\title{
Deterioration Index of Acrylic Top Coat by Raman Spectroscopy
}

by

\author{
Satoshi TaKayA*, Yuki Nishina**, Yohei Hamura***, \\ Takuji YamadA****, Yoichi Tsukuda****, Takashi Yamamoto* and Yoshikazu TAKahashi*
}

Recently, aging of infrastructures constructed in large amount during high economic growth period is becoming one of social problem. Because water is necessary for almost of all deteriorations of concrete structures, organic coating materials are often used for preventing water. It is well known that organic coating materials are deteriorated by ultra-violet ray with time, and accelerated weathering test is carried out for evaluating weatherability of coating materials. However, details of deterioration mechanism of organic coating materials are still unclear and relationship between weathering test and deterioration by sunlight is not made clear. Therefore, quantitative evaluation method of deterioration of organic coating materials has not been established so far.

Then in this study, Raman spectroscopy is focused on as an available method in fields, it was tried to develop deterioration index of organic coating materials with Raman spectroscopy. As results, it was made clear that fluorescence increases with propagation of UV deterioration because carbonyl turn into carboxyl due to deterioration. And deterioration of organic coating materials can be evaluated by using photobleaching of fluorescence peak in Raman spectrum.

Key words:

Acrylic top coat, UV degradation, Deterioration index, Raman spectroscopy, Photobleaching

\section{1 緒言}

近年，高度経済成長期に大量に建設された社会基盤構 造物の老朽化が社会問題となっている。コンクリート構 造物の代表的な劣化には，内部鋼材の腐食やアルカリシ リカ反応, 化学的侵食, 凍害などが挙げられるが, これ らの劣化の多くは水を介在するものであり, 劣化を防ぐ ために表面被覆材としてコンクリート表面に有機系表面 被覆材が施工されることも少なくない。表面被覆工法は 一般に, 表面被覆材の塗布対象となる表面の下地処理を 行った後, 中塗り剂と塗布対象の面の接着性を良くする ためにプライマーを塗布し，表面保護材としての機能を 有する中塗り材を塗布する. さらに最後に中塗り材を保 護するために耐久性の高い上塗り材が塗布されることが 多い. 有機系塗膜は基本的に紫外線により劣化するが, 中塗り材は耐久性に乏しいエポキシ樹脂などが用いられ るため，上塗り材が劣化した後はその性能が大きく低下 することが知られている，例えば渡辺らは ${ }^{1)}$, 様々な種類 の表面被覆工法を実構造物に適用した結果，中性化に対
する抵抗性等において未施工のものに比べ，かなりの向 上が見られたが，暴露の期間が長くなるに応じて表面被 覆材の付着強度や劣化因子に対寸る抵抗性が施工後に比 べ低下していることが確認され，表面被覆材が暴露期間 に応じて劣化していることを報告している. しかし, 塗 膜の耐候性は屋内においてキセノンランプなどを照射し てどれだけ性能を維持できたかで判断することがほとん どであり，促進而候性試験で例えば 3000 時間性能を維持 できたものが実環境においてどれだけ性能を維持できる かは良く分かっていないのが現状である。また実構造物 において，現場で有機系表面被覆材の劣化を評価する手 法として光沢保持率などが用いられることもあるが，塗 膜劣化のメカニズムには不明な点も多く, 定量的な劣化 度評価手法が確立されていない。

一般的に高分子材料の劣化過程の評価には赤外(IR)分 光法が用いられるが, 赤外(IR)分光法では水の影響が大き いため，現場で微小な変化を評価できない可能性がある と考えられる，そこで本研究では，現場で評価可能な手

$\dagger$ 原稿受理 平成31年1月17日 Received Jan. 17, 2019 C2019 The Society of Materials Science, Japan

* 正 会 員 京都大学大学院 工学研究科 社会基盤工学専攻 干615-8540 京都市西京区 Dept. of Civil and Earth Resources Eng., Kyoto Univ., Nishikyo-ku, Kyoto 615-8540

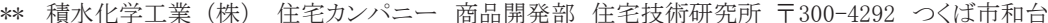
Sekisui Chemical Co. Ltd., Housing Company, Wadai, Tsukuba 300-4292

*** 正 会員 (株)島津テクノリサーチ 試験解析事業部 干604-8436 京都市中京区

Shimadzu Techno-Research, Inc., Testing and Analysis Div., Nakagyo-ku, Kyoto 604-8436

****正 会 員 一般財団法人 日本塗料検査協会 西部支部 テ573-0164 枚方市長尾谷町 Japan Paint Inspection and Testing Association, West Branch Office, Nagaodani, Hirakata 573-0164 
法としてラマン分光法に着目し，コンクリートの表面被 覆材として用いられる有機系上塗り材の劣化指標を作成 寸ることを試みることとした。

\section{2 促進耐候性試験}

\section{$2 \cdot 1$ 試験条件}

使用した表面被覆材は Table 1 に示す 2 種類で，市販の JIS モルタルにメーカー指定の規定量の塗布および養生を 行った。 その後, キセノンランプを用いた促進耐候性試 験を実施した。促進而候性試験の条件は以下の通りであ る. 光源としては太陽光の波長帯に近いキセノン光 ${ }^{2)}$ 用した。

照射光 : キセノン光

照射環境：120 分照射中に 18 分間水が噴霧される

照射時間：0h，100h，500h，1000h，3000h

供試体数 : 各 $\mathrm{n}=2$

各照射時間の促進耐候性試験後に，ひび割れ追従性試 性験およびラマン分光分析を行った．なお，ひび割れ追 従性試験には $40 \times 120 \times 10 \mathrm{~mm}$ の試験体を，ラマン分光分 析には $70 \times 150 \times 20 \mathrm{~mm}$ の試験体をそれぞれ用い，ひび割 れ追従性試験体は，表面被覆材そのものの延びを評価す る必要があり，表面被覆材と基板の付着を切るために， あらかじめひび割れを導入してから表面被覆材の塗布を 行った.

\section{$2 \cdot 2$ ひび割れ追従性試験}

ひび割れ追従性試験は JSCE-K 532 に準じて行った．各 照射時間における 2 体の平均值を Fig. 1 に示す. A につい てはバラつきが大きかったが，塗膜の種類によらず，照 射時間が増えるにつれてひび割れ追従性が低下している のが分かる．特に，表面被覆材 A ではキセノン照射 500 時間以降，表面被覆材 B ではキセノン照射 100 時間以降 にひび割れ追従性の大きな低下が見られる。これは，上 塗り材が劣化し，紫外光が中塗り材まで届いたことが原 因であると考えられる.

\section{$2 \cdot 3$ ラマン分光分析}

本実験では，現場測定に用いることのできるポータブ ルタイプのラマン分光装置を使用し, 励起光として $532 \mathrm{~nm}$ のレーザーを用いた。 それぞれの供試体に対して Fig.2 に 示す 3 点で測定を行った。照射時間ごとに平均化したス ペクトル Fig.3 に示す. $450 \mathrm{~cm}^{-1}$ と $600 \mathrm{~cm}^{-1}$ のピークはルチ ル型の $\mathrm{TiO}_{2}$ に由来寸るのもので，特に表面被覆材 $\mathrm{B}$ で強 く現れているが，表面被覆材 $\mathrm{A}$ でもキセノン照射前の試 験体ではピークを確認することができ，表面被覆材 A，B ともに白色顔料としてルチル型 $\mathrm{TiO}_{2}$ が入っていることを 表している. Fig.3 を見ると, 約 $1750 \mathrm{~cm}^{-1}$ を頂点とするな だらかな山状のスペクトルが見られ，キセノン照射時間 が長くなるにつれて山状のピークが大きくなっているこ とが分かる。この現象は「蛍光」(fluorescence)と呼ばれる 現象である. Fig.4 に蛍光現象のメカニズムを示す。 ラマ ン分光法は励起光を物質にあてることで仮想励起状態に し，その返ってくる光のエネルギーの減少，すなわち波
Table 1 Coating materials used in this study.

\begin{tabular}{|c|c|c|}
\hline & A & B \\
\hline Top coating material & Acrylic urethane & Acrylic emulsion \\
\hline Main coating material & Epoxy resin & Epoxy resin \\
\hline Curing Conditions & $23^{\circ} \mathrm{C} 50 \% \mathrm{RH}$ & $23^{\circ} \mathrm{C} 50 \% \mathrm{RH}$ \\
\hline Curing Period & 28 days & 28 days \\
\hline
\end{tabular}
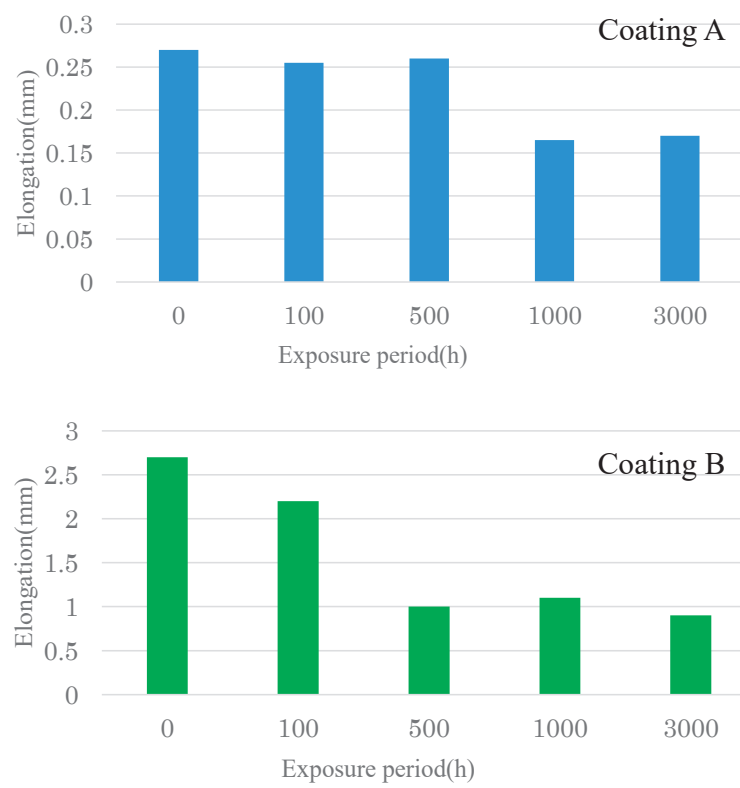

Fig.1 The results of crack elongation test.

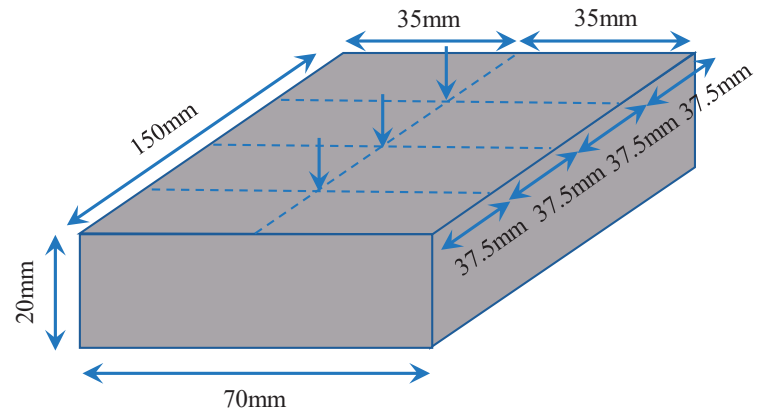

Fig.2 Sampling points of Raman spectroscopy.

長の伸びを見る分析方法であるが，蛍光はその仮想励起 状態が S1 励起状態まで到達し, その状態で一度安定化す るためエネルギーが下がり，結果として波長が伸びるた めスペクトル上に表れてしまうことを表している. Fig.5 は表面被覆材 A のキセノン照射 $100 \mathrm{~h}$ 後に同じ場所を $532 \mathrm{~nm}$ と $785 \mathrm{~nm}$ の二つの励起光で測定したラマンスペク トルを表している，図を見ると，532nm の入射光を用い た場合に観察された山状のピークが， $785 \mathrm{~nm}$ の入射光を 用いた場合には見られないことが分かる。これは，エネ ルギーの小さい $785 \mathrm{~nm}$ では $\mathrm{S} 1$ 励起状態に到達しないため であり，このことからも山状のピークが蛍光に起因する ものであることが分かる，蛍光現象が生じると，ラマン スペクトル上で分子構造に起因するピークが見えにくく なることから，蛍光を生じないようにラマン分光分析を 行うのが一般的であるが，表面被覆材の劣化に伴い蛍光 に起因するピークの上昇が見られたことから，蛍光現象 により生じる山状ピークの大きさが表面被覆材の劣化指 


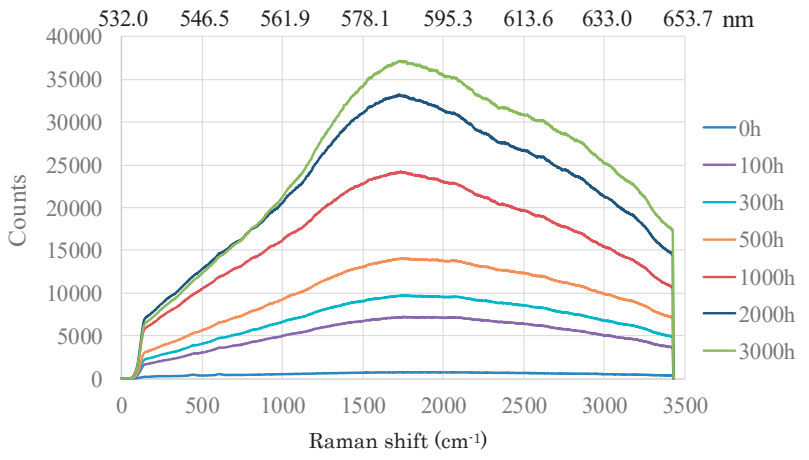

(a) Coating A

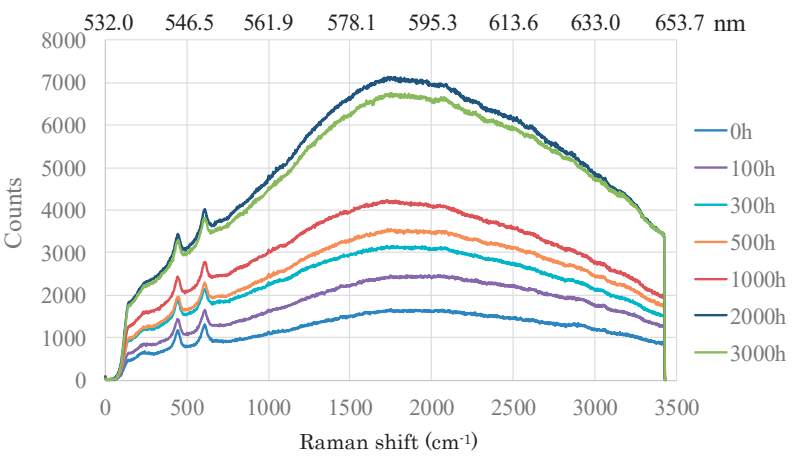

(b) Coating B

Fig.3 The results of Raman spectroscopy analysis.

標となりえると考えられる. しかし，劣化の進行に伴い， 表面被覆材のどのような構造変化が蛍光現象の原因にな ったかが分からないと，蛍光現象が表面被覆材の劣化に よるものかどうかが分からないため，表面被覆材の劣化 による構造変化が蛍光現象の原因になっていることを確 認することとした.

\section{3 表面被覆材の劣化による蛍光発生メカニズム}

表面被覆材の劣化による蛍光発生メカニズムを検討寸 るために, まずは表面被覆材 $\mathrm{A}$ のキセノン照射 $0 \mathrm{~h}$ および $3000 \mathrm{~h}$ の赤外(IR)分光分析を行い，劣化に伴う分子構造の 変化を調べることとした. 赤外(IR)分光分析の測定には, 樹脂表面を一部カットして Attenuated Total Reflection (ATR) 法により行った。その結果を Fig.6 に示す。図を見 ると, 表面被覆材の劣化に伴い, $1146 \mathrm{~cm}^{-1}\left(-\mathrm{CH}_{3}\right), 1236 \mathrm{~cm}^{-1}$ $\left(-\mathrm{CH}_{3}\right), 1452 \mathrm{~cm}^{-1}\left(-\mathrm{CH}_{2}-,-\mathrm{CH}_{3}\right), 1722 \mathrm{~cm}^{-1}$ (-COO-), $2945 \mathrm{~cm}^{-1}$ $\left(-\mathrm{CH}_{3}\right)$, のスペクトル強度が小さくなっており, 一方で $1623 \mathrm{~cm}^{-1}, 1765 \mathrm{~cm}^{-1}, 3394 \mathrm{~cm}^{-1}(-\mathrm{OH})$, のスペクトル強度 が大きくなっていることが分かる．劣化したアクリルメ ラミン樹脂を赤外分光により分析を行った知ら ${ }^{3)}$ ると $1765 \mathrm{~cm}^{-1}$ は過酸化エステルに由来するスペクトルで あると報告されているが，過酸化エステルは通常のエス テルよりも不安定な場合が多く，また $1722 \mathrm{~cm}^{-1}$ のエステ 儿結合が減少していることを踏まえると，紫外線によっ てエステルが分解され過酸化状態になっているとは考え にくい，そのため，ピークの帰属を知るために分子軌道 法による IR スペクトル解析を行った．藤本らは，ポリウ レタンの光分解に Norrish 反応II型があることを報告 ${ }^{4)}$ ており,この反応が生じると反応後に R-NHCOOH が生成 することになる. また， R-NHCOOH が加水分解すること により $\mathrm{R}^{\prime}-\mathrm{NH}_{2}$ が生じることが報告 ${ }^{5) さ れ て い る . ~ そ こ て ゙, ~}$ IR スペクトルの解析対象として R-NHCOOH および $\mathrm{R}^{\prime}-\mathrm{NH}_{2}$ とした。解析結果を Fig.6 に合わせて示す. 解析の 結果, $1765 \mathrm{~cm}^{-1}$ が-COOH $の \mathrm{C}=\mathrm{O}$ 伸縮であることが分かっ た。また， $1623 \mathrm{~cm}^{-1}$ のピークは- $\mathrm{NH}_{2}$ のはさタ振動である ことが分かった。これらの結果から想定される劣化に伴 う構造変化を Fig.7 に示す. ウレタン結合の光分解の中間 生成物で生じる R-NHCOOH が分解されている一方で,

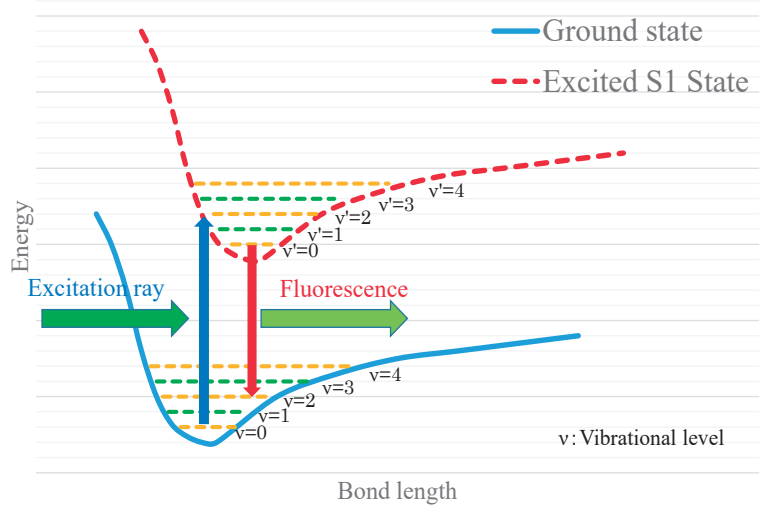

Fig.4 The Emission mechanisms of fluorescence.

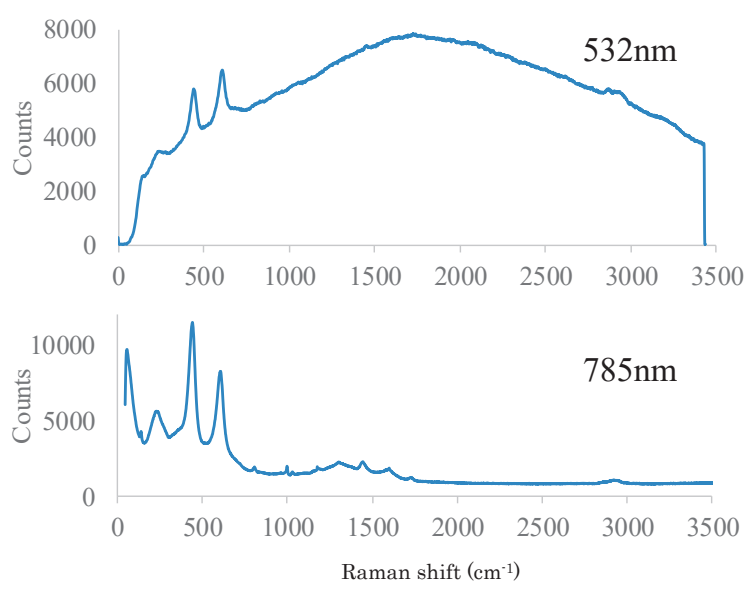

Fig.5 Difference of peak between $532 \mathrm{~nm}$ and $785 \mathrm{~nm}$.

-COOH が 3000h にて増加していることを考慮すると Fig.7 に示すアクリル側におけるエステル結合が加水分解され ていることが考えられる。このことは， $3394 \mathrm{~cm}^{-1}(-\mathrm{OH})$ の ピークがキセノン照射 $3000 \mathrm{~h}$ 後に増加していることから も裏付けられる。これは, ポリエステルやポリウレタン の加水分解にかなり近い反応であると考えられる.

次に，この構造変化に伴いラマンスペクトル上で蛍光 に起因するピークが大きくなるかどうかを, 分子軌道法 により検討することとした. 分子軌道法とは分子中の電 子が単なる原子間結合としての夕存在しているのではな く，原子核や他の結合電子の影響を受けて存在している 


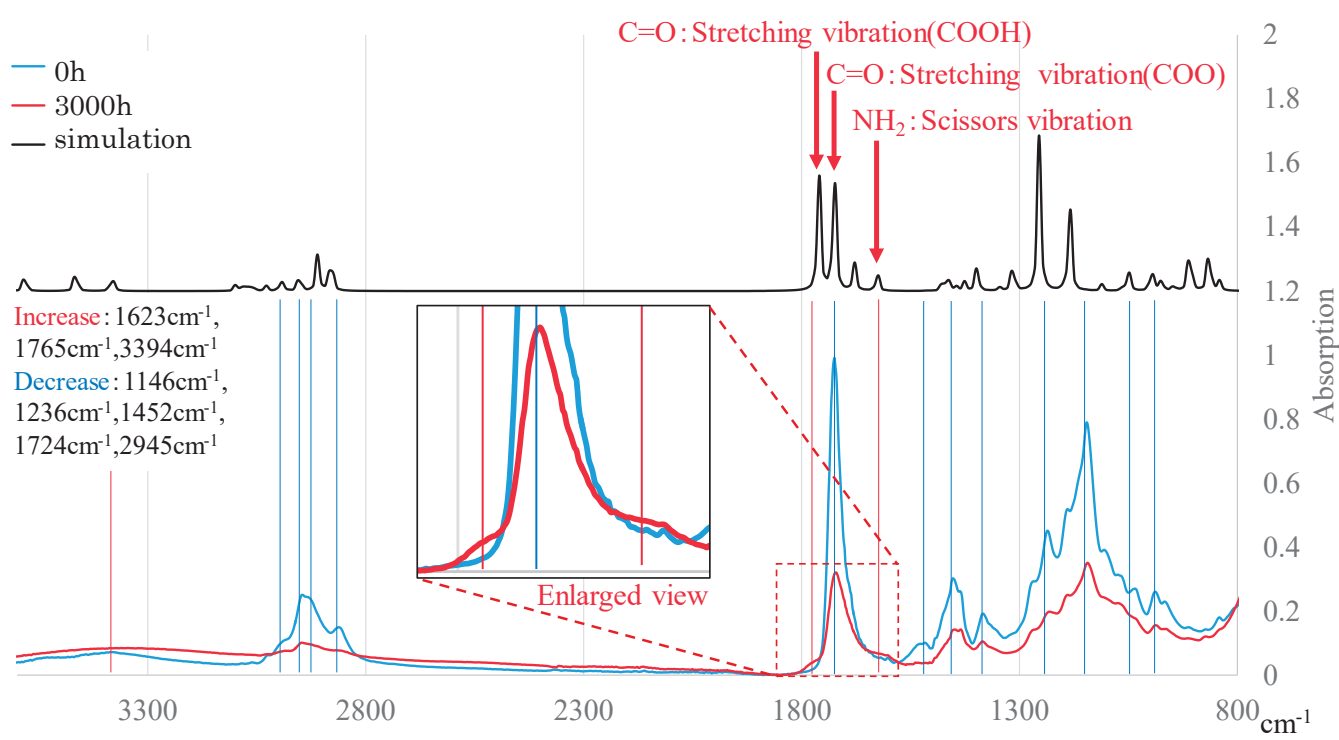

Fig.6 The results of numerical analysis and FTIR of coating A after Xenon irradiation for 0h and 3000h.

と考え，物質における電子の状態を数值計算で出す手法 である．物質における電子の状態は量子力学に支配され ており，相対論的な効果を除けば，Schrödinger 方程式を 解くことによって，再現することが可能である．本研究 では，Schrödinger 方程式の代わりに，時間に周期的に依 存する電子状態に対する時間依存 Kohn-Sham 方程式を用 いて一電子励起状態における構造最適化を行い, 振動数 計算は時間依存密度汎関数理論法(TDDFT)によって行っ

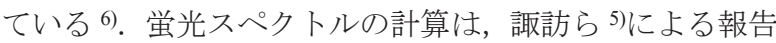
を参考にして行った. 両状態ともに基底関数に 6-31+G(d), 汎関数にB3LYPを用いた。

エステル結合が切れることで蛍光スペクトルがどのよ うに変化するのかを検討するために，解析対象は Fig.8 に 示す二つのパターンで行った.解析の結果を Fig.9 に示す. 図を見ると，エステル結合を有する Target1 では概ね $630 \mathrm{~nm}$ の波長の蛍光が，エステル結合が切れて-COOH と なった Target2 では概ね 590nm の波長の蛍光が現れており， エステル結合が切れることで蛍光のピークが大きくなっ ていることが確認できる．ラマンスペクトルでは横軸が 入射光に対して波長が伸びて帰ってきた波と入射光の波 数（波長の逆数）の差となっている. 入射光 $532 \mathrm{~nm}$ およ び $590 \mathrm{~nm}$ の波長の波数を計算すると，532nm の波数が $18797 \mathrm{~cm}^{-1}, 590 \mathrm{~nm}$ の波数が $16949 \mathrm{~cm}^{-1}$ となり，波数の差 は $1848 \mathrm{~cm}^{-1}$ となる. Fig.3 の分析結果では，蛍光ピークは $1750 \mathrm{~cm}^{-1}$ であるが, この違いは促進耐候性試験で用いた表 面被覆材と解析モデルの官能基の違いに起因すると考え られる. また, Fig.3においてもキセノン照射 $0 \mathrm{~h}$ に対して 照射時間が長くなるにつれて蛍光のピークが若干低波数

（左）側にシフトしていることを考慮すると，解析結果 は妥当であると考えられ，表面被覆材の劣化によりエス テル結合が切れ，-COOH が増加することにより蛍光のピ 一クが大きくなると考えられる.
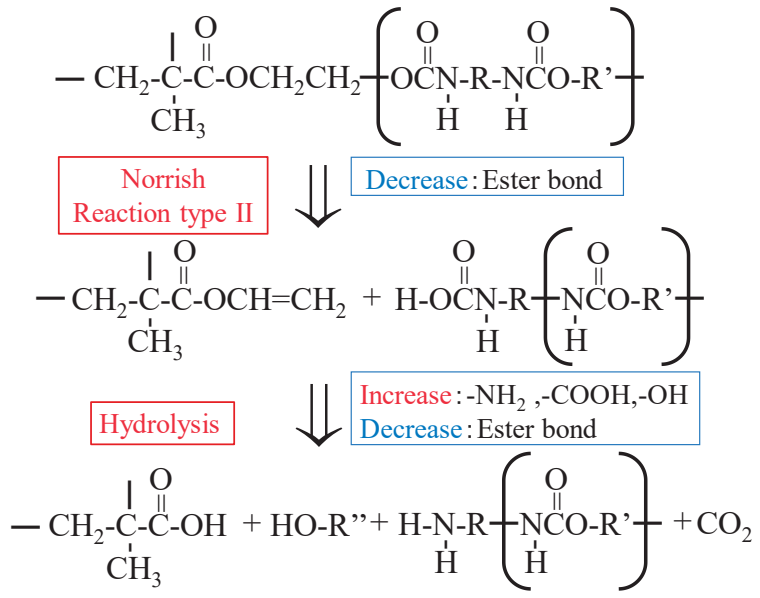

Fig.7 The example of Acrylic urethane photolysis.

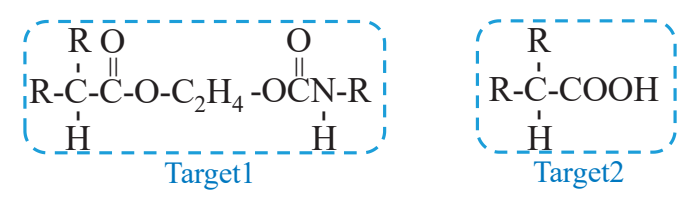

Fig.8 Target of fluorescence peak calculation.

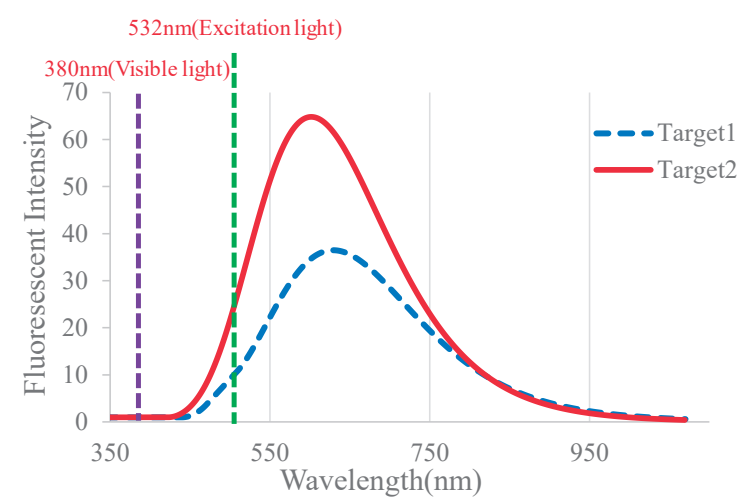

Fig.9 The calculation results of fluorescence spectrum. 


\section{4 劣化指標の提案}

これまでの検討で, 表面被覆材は紫外線により劣化す ることでエステル結合が切れ，-COOH が増えることによ り，ラマンスペクトル上で蛍光のピークが大きくなるこ とが分かった．したがって，蛍光のピークの大きさを利 用することにより，表面被覆材の劣化度を定量的に評価 できる可能性があるが，ラマンスペクトルのピークは焦 点距離や表面の凹凸，レーザー強度などの様々な要因に より変化するためピーク強度そのものを指標として用い ることができない. そのため, 蛍光のピーク強度を無次 元化する必要があるが，本研究では光退色現象に着目し た，光退色とは Fig.10 に示すように，同じスポットに励 起光を当て続けると蛍光強度が小さくなっていく現象で ある。

$\mathrm{S}$ : 相対蛍光強度, $f n: \mathrm{n}$ 分後の蛍光強度, $\mathrm{F}_{0}$ : 初期蛍 光強度として,

$$
\mathrm{S}(\%)=f n / \mathrm{F}_{0} * 100
$$

という初期蛍光強度に対しての各時間における蛍光強度 の相対比をプロットすると光退色曲線を描くことができ る.この曲線を表面被覆材 $\mathrm{A} ， \mathrm{~B}$ について描いたものを Fig.11 に示す. なお, 図中の光退色曲線は供試体 2 体の平 均值を用いて描いたものである，材料の違いにより，劣 化による光退色曲線の変化の仕方に差はあるものの， い ずれの表面被覆材も劣化の進行により光退色が遅くなっ ていることが確認できる，一般に，その測定面積におい て蛍光を発する物質の濃度が高いほど光退色は遅くなる ことが報告されており 7),8)，本研究においても，照射時間 が長くなるにつれて蛍光をより強く発する物質が増えた ためにこのような結果となったと考えられる．表面被覆 材 $\mathrm{A}$ に比べて表面被覆材 B の光退色が早いが，これは表 面被覆材 B の方が蛍光物質（ここでは-COOH）の濃度が 低いためと考えられ，材料によって紫外線劣化により生 じる蛍光物質の濃度が異なる可能性が高い. したがって, あらかじめ現場で評価したい表面被覆材の促進耐候性試 験を行い, 光退色曲線を得られていれば, 現場で光退色 曲線を測定することで表面被覆材の劣化度を定量的に評 価できる可能性があると考えられる.

\section{5 暴露試験体との比較}

ここまで促進耐候性試験を行った結果に基づいて検討 を行い, 光退色曲線を利用することにより，表面被覆材 の劣化度を評価できる可能性が示された。しかし, キセ ノン光と太陽光では波長やエネルギーの違いなどもある ため, 劣化メカニズムが促進耐候性試験と実構造物では 異なる可能性がある. そのため, 暴露試験体においても 光退色曲線を用いた評価が可能であるかの検討を行うこ ととした. 本研究では, 日本材料学会所轄のコンクリー 卜工事用樹脂部門委員会（補修用樹脂小委員会）におい て，以下の条件で暴露した試験体を使用した.

使用材料 : A1，B1

暴露年数 : $0,1,3,5,10$ 年 $($ 各 $\mathrm{n}=3)$

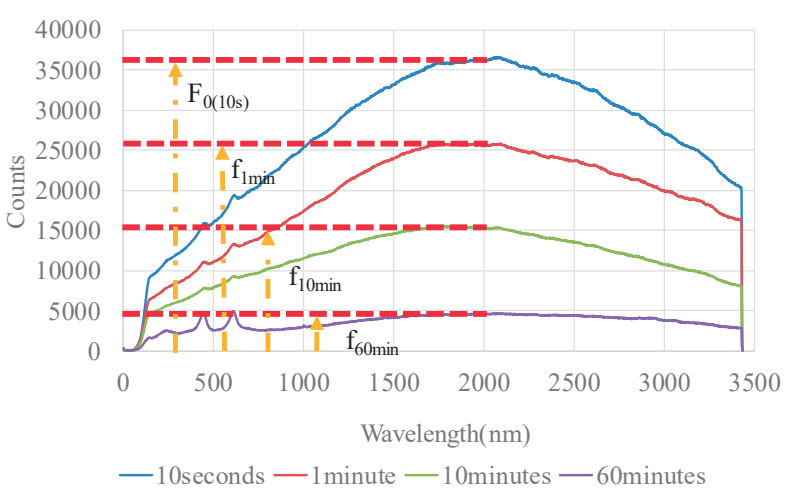

Fig.10 Photobleaching of coating B after Xenon 3000h irradiation.
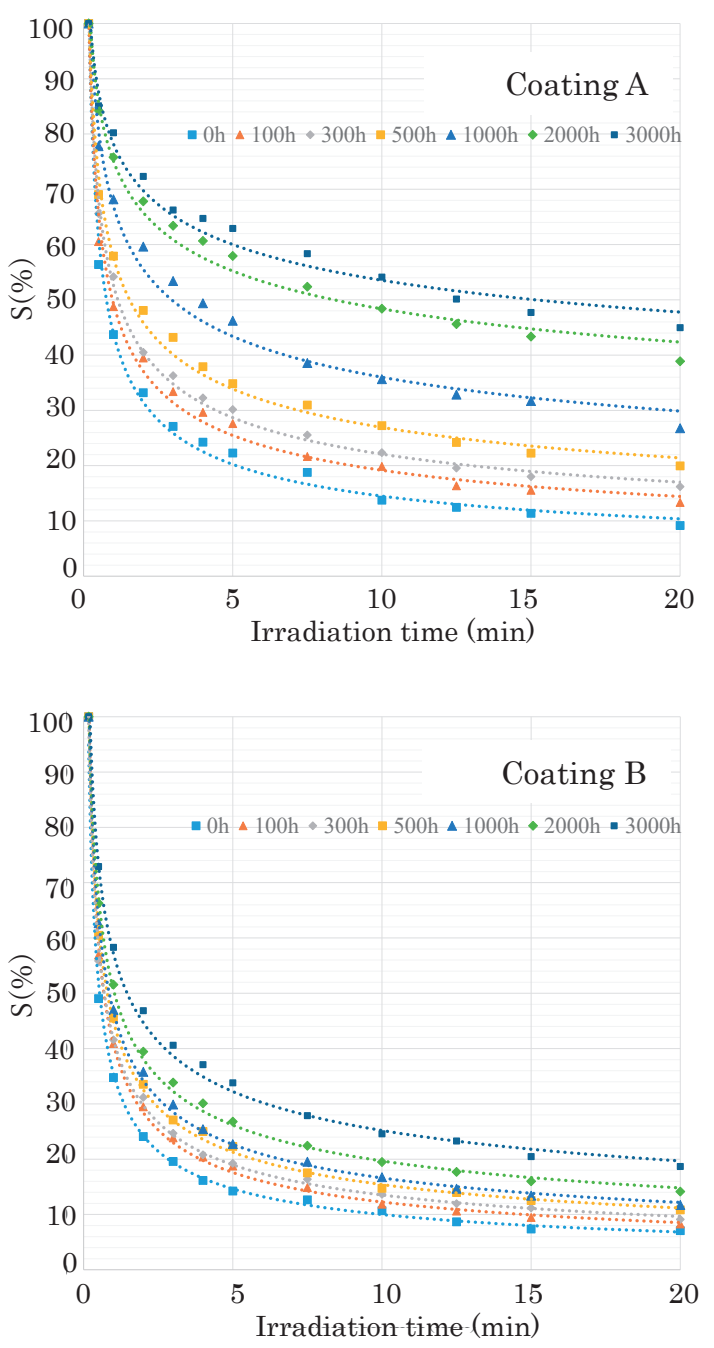

Fig.11 Obtained photobleaching curve.

暴露環境 : 銚子暴露試験場 (一般財団法人日本ウエザ リングテストセンター)

使用材料の A1, B1 は, 促進耐候性試験で用いた表面被 覆材 $\mathrm{A}, \mathrm{B}$ とそれぞれ同じメーカーの同一系統の製品であ るが，10 年前と細かな配合等が異なる可能性が考えられ るため，本論文では異なる材料名を用いている．また， 暴露年数が異なる供試体を 10 年前に一斉に暴露しており, 例えば暴露 3 年は暴露開始 3 年後に暴露試験を終了し, 
その後 7 年間アルミホイルに包まれた状態で保存されて いたことに注意が必要である.

光退色曲線の測定結果を Fig.12 に示す。図を見ると， 表面被覆材 $\mathrm{A} 1, \mathrm{~B} 1$ ともに促進耐候性試験で用いた表面被 覆材 $\mathrm{A}, \mathrm{B}$ の光退色曲線と同様の傾向を示し，B1 の方が A1 に比べて光退色が早い結果となっている．しかし，促 進試験で用いた表面被覆材 A，Bのキセノン照射 $0 \mathrm{~h}$ にお ける光退色 20 分後の相対蛍光強度が $10 \%$ 以下であったの に対し, 暴露試験体 A1, B1 では暴露 $0 \mathrm{y}$ でも $10 \%$ を超え ており，光退色が遅くなっている．この原因として，暴 露 $0 \mathrm{y}$ の供試体でも, 10 年前に作製されたものであるため, 10 年間の間に若干劣化が進行したためと考えられる.

促進試験体と暴露試験体を比較すると, 細かい配合の 違い等がある可能性はあるものの，概ね同様の傾向を示 したことから，促進試験と暴露試験で劣化のメカニズム には大きな違いはないと考えられる. 本実験では光退色 20 分まで測定測定しているが，現場測定を考えると測定 時間は短い方が望ましいため, より短い光退色の測定結 果で評価する手法について今後さらに検討する必要があ る。また本研究では，アクリル系の上塗り材を用いた表 面被覆材について検討を行ったが，その他の上狳り材に ついても今後検討する必要がある.

\section{6 結 言}

本研究で得られた主な結論は以下の通りである.

1) アクリル系上塗り材が紫外線により劣化すると, エ ステル結合が切れて-COOH が生じる.この構造変化 が起こることにより，ラマンスペクトル上で蛍光が 生じ，劣化の進行に伴い蛍光強度が大きくなる.

2）ラマンスペクトル上の蛍光強度を無次元化するため に，光退色に着目した結果，光退色曲線を描くこと により表面被覆材の劣化度を定量的に評価できる可 能性が示された。

3) 促進耐候性試験体と暴露試験体の光退色曲線を比較 した結果，同様の傾向を示したことから，試験方法 の違いによる劣化メカニズムの大きな違いはないと 考えられる。

本研究は，科学研究費助成事業（課題番号18K18880）によ り行ったものである.

\section{参 考 文 献}

1) Y. Watanabe, S. Aramaki, Y. Matsuda, T. Yamada and T Miyagawa "Evaluation of concrete surface coating method applied to San-yo Shinkansen RC structures", Journal of the Society of Materials Science Japan, Vol.58, No.8, pp.661-696, (2009).

2) Public Interest Incorporated Association, Japan Paint Manufacturs Association "Various weather resistance testing machine investigation report”, (2003).
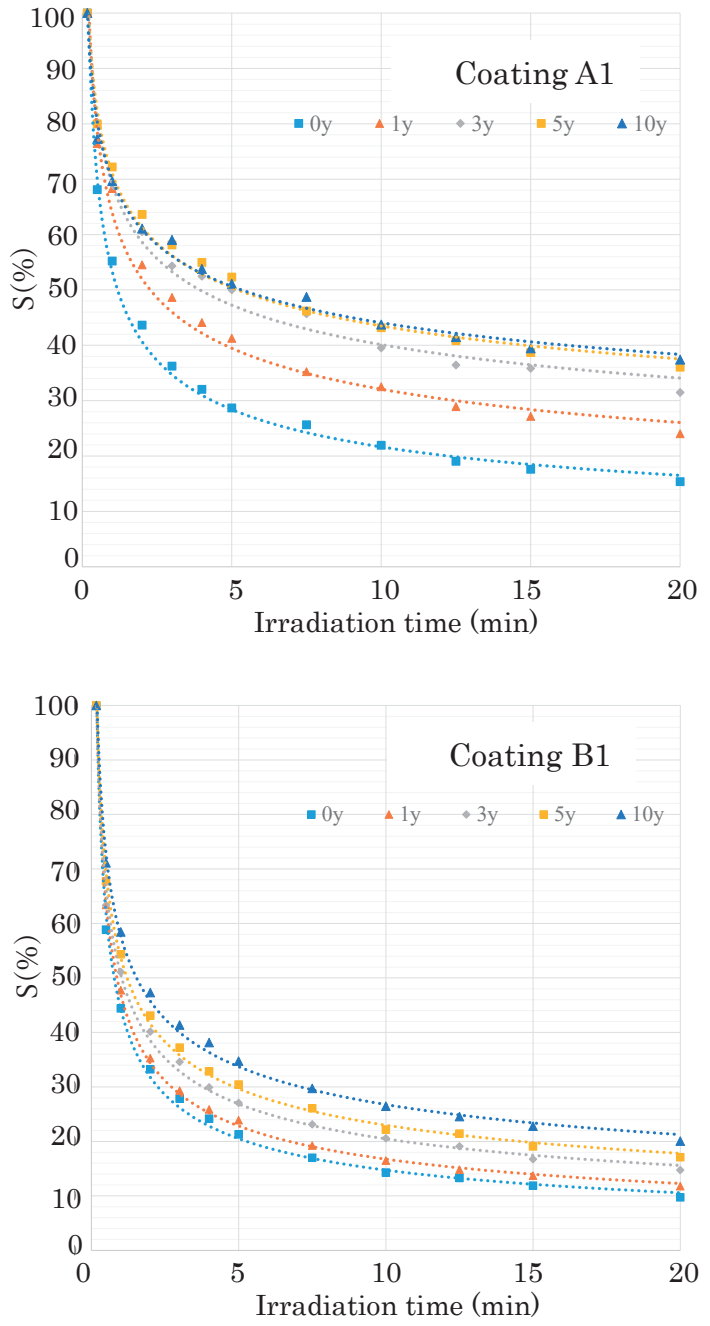

Fig.12 Photobleaching curve of exposed specimen.

3) M. Yabe, S.Tagiri and Y. Okamoto "Analysis of degradation process of organic coatings in various weathering tests", Toryo no Kenkyu, No.146,(2006)

4) E. Fujimoto and K. Nakamura "Analysis of photo decomposition mechanism by Polyurethane FT-IR-ATR and DMA", Japanese Journal of Polymer Science and Technology, Vol. 51, No. 9, pp. 612-618 ( 1994).

5) S. Suwa, Y. Kawashima, R. Kawashita, Y. Huji, T. Tau, H. Fujioka, M. Arisawa and T. Takagi, "Examination of spectrum accuracy by molecular orbital calculation", The 39th Chemoinformatics Debate (2016).

6) T. Tsuneda, "Fundamental of density functional theory", Kodansha, Ltd. (2012).

7) T. Miyagawa, S. Watanabe, A. Yokoyama and K. Kuroda, "The fading rate of magenta Pyrazolone Azomethine dye for visible light", The journal of the Society of Scientific Photography of Japan, Vol.35, No.3, pp.168-173 (1972).

8) Y. Honma, N. Choji and M. Karasawa "Effect of dye concentration distribution on photofading of disperse dye in Cellulose Triacetate", Fiber, Vol.42, No.9, pp.72-78 (1985). 